\title{
Bacterial Population Associated with Fruits and Vegetables and its Treatment using Antimicrobial Rinsing
}

\author{
Amandeep Kaur*, Anchal Sood, Sarbjit Kaur and Priyanka Bhowate
}

Dolphin College of Life Sciences, Chunni Kalan Dist. Fatehgarh Sahib, Punjab, India

*Corresponding author

\section{A B S T R A C T}

Fruits and vegetables are one of the essential diets of human being, which they are consumed widely. But, they are contaminated with different bacteria that may cause food borne illness. Bacteriological survey of 20 samples of fresh vegetables and fruits were done to study the density of microorganisms by standard plate count (SPC) method. The colony forming units per gram $(\mathrm{cfu} / \mathrm{g})$ of the vegetables were much less $\left(7.2 \times 10^{5}\right.$ to

\section{Keywords}

Fruits, Vegetables, food pathogens, Microbiological load,

Bacteriological analysis.

\section{Article Info}

Accepted:

17 October 2017 Available Online: 10 December 2017 $\left.30.4 \times 10^{5}\right)$ in local market sample as compared to super market sample $\left(12.0 \times 10^{5}\right.$ to $\left.20.6 \times 10^{5}\right)$ and field sample $\left(8.0 \times 10^{5}\right.$ to $\left.18.0 \times 10^{5}\right)$. But in case of fruits higher cfu were obtained for the field sample $\left(8 \times 10^{5}\right)$ as compared to local market sample $\left(4 \times 10^{5}\right.$ to $\left.5.5 \times 10^{5}\right)$ and super market sample $\left(2.5 \times 10^{5}\right)$. Of the various pathogens identified from the surface of these samples Escherichia coli, Staphylococcus aureus, Bacillus cerous were found to be the pre-dominant species in most of the samples. It was observed that the Bacillus, Enterobacter and Staphylococcus were the dominant genera in vegetables. On the basis of antimicrobial rinsing of carrot, which was carrying the highest bacterial contamination, five different anti-microbial agents (Hydrogen peroxide, Sodium chloride, Calcium chloride, Sodium citrate and Ethanol) decreased the total number of microbial organisms' load of the carrot by 40-80 per cent. Hydrogen peroxide was, however, found to be the most effective, as rinsing treatment with it showed more reduction in total number of bacterial organisms in 80 per cent of samples. Hydrogen peroxide can thus be used as rinsing agent to reduce this type of superficial bacterial contamination so as to improve the quality of fresh vegetables and fruits for human consumption. The microflora of fruits and vegetables are one of the great concerns in our society as they can be of great risk for human health. Proper handling, hygiene, transportation and proper storage is necessary to avoid microbial food spoilage and related health risks.

\section{Introduction}

Fresh fruits and vegetables are an important source of nourishment, especially vitamins, and a vital ingredient in healthy and balanced diets. Fruits and vegetables are vital sources of Nutrients to human beings. They give the body the necessary vitamins, fats, minerals, and oil in the right proportion for human growth and development. Fruits and vegetables however, have serious challenges to their existence. These include changes in climatic condition, pests and microbial attack. Over the years, there has been an increase in the need to identify and isolate the microorganisms associated with the spoilage as a way of finding a means of controlling it (Akinyele and Akinkunmi, 2012). Fresh 
produce is highly recommended in any diet, virtually without quantitative restriction (Silva et al., 2007). Susceptibility of fruits and vegetables is largely due to differential chemical composition such as $\mathrm{pH}$ and moisture contents are associated with greater predisposition to microbial spoilage.

Cabbage (Brassica oleracea capitata), Brinjal (Solanum melongena L.), Tomato Lycopersicon esculentum, (Solanaceae), Cauliflower (Brassica oleracea var Botrytis) and Carrots (Daucus carata L.) are the important vegetables grown in India (Mansoor Hassan et al., 2005; Wasim et al., 2008; Felix and Mahendran, 2009). Ber (Ziziphus mauritiana), Grapes (Vitis) and Chickoo (Sapodilla) has been recognised as a useful edible fruits since antiquity in India (Einsett and Pratt, 1975; Asam Ali et al., 2006). Such and other fresh-cut vegetables are, therefore, offered as salads in more than 70 per cent of fast food establishments and family restaurants. These vegetables and fruits are, however, capable of causing human diseases while still on the plant in fields or orchids, or during harvesting, transport, processing, distribution and marketing, or in the home (FDA, 2000; Joshi, 2008). Salmonellae have been isolated from many types of raw fruits and vegetables (Beuchat, 1996; Wells and Butterfield, 1997). Bacteria such as Clostridium botulinum, Bacillus cereus and Listeria monocytes, all capable of causing illness, are normal in habitants of many soils, whereas Salmonella, Shigella, Escherichia coli and Campylobacter reside in the intestinal tracts of animal, including humans and more likely to contaminate raw fruits and vegetables through contact with their faeces, sewage, untreated irrigation water or surface water (Cliver, 1997; Speer, 1997). The incidence of food borne outbreaks caused by contaminated fresh fruit and vegetables has increased in recent years (Mukherjee et al., 2006). There is thus demand by the consumers to use only such fresh vegetables and fruits which are free from microbial contamination and safe for human consumption. In the developed world, the extensive use of antibiotics in agriculture, especially for prophylactic and growth promoting purposes, has generated much debate as to whether this practice contributes significantly to increased frequencies and dissemination of resistance genes into other ecosystem (Chikwendu et el., 2008). Differences in microbial profiles of various fruits and vegetables result largely from unrelated factors such as resident micro flora in the soil, application of non-resident micro flora via animal manures, sewage or irrigation water, transportation and handling by individual retailers. Keeping the above facts in mind the present study on 'bacterial population associated with fresh fruits and vegetables and the treatment of carrot - a commonly used fresh vegetables as saladusing antimicrobial agents, so as to reduce the microbial contamination of the fresh fruits and vegetables before their consumption as raw, was designed with the following objectives.

Isolation and enumeration of bacteria in different samples of fresh fruits and vegetables.

Morphological, biochemical and physiological characterization of bacterial strains.

Antimicrobial profile of surface micro flora of fruits and vegetables.

Effect of different antimicrobial agents on fruits and vegetables.

\section{Materials and Methods}

Three fruits namely Ber, Grapes and Chickoo and five vegetables namely Cabbage, Carrot, 
Brinjal, Tomato and Cauliflower were selected in the present study. The samples were collected from Local market (LM), Super market(SM) and Field (F), thorough survey of market was carried out in the month of February and March, for the collection of the samples of fresh fruits and vegetables available in the market so as to check the variation in the superficial bacterial contamination and reduce the same through antimicrobial rinsing treatment.

Following methodologies were used to check the variation in bacterial population load and its antimicrobial treatment.

\section{Isolation and estimation of bacterial population}

For the isolation of bacterial strain from different samples, serial dilutions of the samples were prepared.

The respected sample was suspended in 90ml distilled water and serial dilution was prepared. $0.1 \mathrm{ml}$ sample was taken, spread it on different selective media, and incubated the plates for 24 hours at $37^{\circ}$.

\section{Calculation of colony forming unit}

After the appearance of colonies on the plates the cfu of each soil sample were calculated using the formula:

Number of colonies appearing on the plate

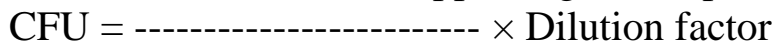

Volume of sample taken

\section{Morphological characterization}

The isolated strains were characterized on the basis of different morphological and physiological characterization as mentioned in Bergey's Manual of Systematic Bacteriology.

\section{Antibiotic resistance profile (Bauer et al., 1966)}

Antibiotic resistance of selected pathogenic isolates was determined by disc diffusion assay on Mueller Hinton agar as per Kirby Bauer method.

\section{Effect of antimicrobial agents on bacterial population (Patel and Joshi, 2008)}

The effect of different antimicrobial agents on the bacterial load of the local market sample of carrot was determined. Sample was treated with five different antimicrobial agents with varying concentration ranging from $0.5-3 \%$.

\section{Results and Discussion}

The present study entitled Bacterial population associated with fruits and vegetables and its treatment using antimicrobial rinsing was carried out to study the micro flora associated with fruits and vegetables and reducing their superficial contamination with antimicrobial rinsing. A comparison among the total microbial load of fruits and vegetables from various markets and field sample was also carried out. Twenty samples were collected from local market, super market and field, and bacterial population was isolated from them. The bacterial strains were characterized on the basis of various morphological and biochemical tests. The strains were screened for antibiotic sensitivity against various antibiotics. Further, treatment of fruits and vegetables was also carried out to study the reduction in total bacterial load. The results of present study are summarized as under:

Data presented in Table 1showed that among vegetable samples the highest cfu (colony forming units) count was obtained for local market samples of carrot i.e. $30.4 \times 10^{5}$ on NAM as compared to super market $\left(20.6 \times 10^{5}\right)$ 
and field sample $\left(18.0 \times 10^{5}\right)$. Among fruits the cfu highest count was obtained for field sample i.e. $8 \times 10^{5}$ (Table 2) as compared to local market sample $\left(5.5 \times 10^{5}\right)$ and super market sample $\left(2.5 \times 10^{5}\right)$. Similar finding were observed by Ibrahim et al., (2009), Patel and Joshi (2008) who observed high contamination and high number of pathogens on the surface of fresh vegetables and fruits in case of local market samples (log 9-10 $\mathrm{cfu} / \mathrm{ml})$ as compared to super market samples $(\log 5-6 \mathrm{cfu} / \mathrm{ml})$.

A total of twenty one bacterial strains were isolated in the present study. On the basis of morphological and biochemical tests ten strains namely VTL4, VCBL7, VTM8, VCL9, VCAM10, VCBM11, FBL18, FGRL17, FGRL15 and FBL21 strains isolated were identified as E. coli. Patel and Joshi (2008) also detected the prevalence of the members of family Enterobacteriaceae among the bacterial population isolated from fruits and vegetables. While, VBL1, VTL5,
VCM6, VTF13, FCHL14, FGRL19, VCF12 and FCHL16 were identified as Staphylococcus aureus and VCM3, VCAL2, FCHL20 were characterized as Bacillus cereus (Table 4). Viswanathan and Kaur (2001) also reported the presence of E. coli and Staphylococcus aureus in vegetables and fruits. Several other workers have also detected Staphylococcus aureus from carrot and ready-to-eat vegetable salads (Abdelnoor et al., 1983; Houang et al., 1991) (Fig. 1-3).

Staphylococcus spp. and E. coli have been reported to be the major microbes associated with the contamination of the vegetables and fruits (Ibeyessie, 2007; Ibrahim et al., 2009). VCM3, VCAL2, FCHL20 were identified as Bacillus cereus. Portnoy et al., (1976) observed the presence of Bacillus spp. while working with raw vegetables and fruits. Presence of spore formers can be attributed to the fact that spore-forming organisms can attach to vegetables grown near the soil for e.g. Bacillus cereus (Linton, 2003).

Table.1 Colony forming unit of vegetables samples collected from different markets

\begin{tabular}{|c|c|c|c|c|c|}
\hline \multirow[t]{2}{*}{ SR. NO } & \multirow[t]{2}{*}{ VEGETABLES } & \multicolumn{4}{|c|}{ Cfu $\left(\times 10^{5}\right)$} \\
\hline & & NAM & MCA & \begin{tabular}{|l|} 
EMB \\
\end{tabular} & MSA \\
\hline \multicolumn{6}{|c|}{ LOCAL MARKET } \\
\hline 1 & Cabbage & 7.2 & - & 3.2 & 3.5 \\
\hline 2 & Cauliflower & 13.6 & 1.1 & 1.3 & 2.3 \\
\hline 3 & Carrot & 30.4 & 6.2 & - & 4.5 \\
\hline 4 & Tomato & 13.2 & 6 & 1.5 & 2.5 \\
\hline 5 & Brinjal & 23.2 & 3 & - & 3.0 \\
\hline \multicolumn{6}{|c|}{ SUPER MARKET } \\
\hline 1 & Cabbage & 20.6 & - & 3.0 & 1.1 \\
\hline 2 & Cauliflower & 12.0 & 1 & - & 1.2 \\
\hline 3 & Carrot & 17.6 & 2.4 & - & 4.4 \\
\hline 4 & Tomato & 16.8 & 1.4 & 2.1 & 1 \\
\hline 5 & Brinjl & 12.0 & - & 2 & 1.0 \\
\hline \multicolumn{6}{|l|}{ FIELD } \\
\hline 1 & Cabbage & 16.0 & 2.5 & - & 1.4 \\
\hline 2 & Cauliflower & 8.0 & 3.5 & - & 2.5 \\
\hline 3 & Carrot & 14.0 & 3.4 & - & 3.0 \\
\hline 4 & Tomato & 18.0 & 6.0 & - & 2.2 \\
\hline 5 & Brinjal & - & - & 1.0 & 1.9 \\
\hline
\end{tabular}

$\mathrm{NAM}=$ Nutrient agar methylene. $\mathrm{MCA}=$ MacConkey agar. $\mathrm{EMB}=$ Eosine methylene blue Agar medium. MSA $=$ Mannitol Salt Agar 
Table.2 Colony forming unit (cfu) of fruit samples collected from different markets

\begin{tabular}{|c|c|c|c|c|c|}
\hline \multirow[t]{2}{*}{ SR.NO } & \multirow[t]{2}{*}{ FRUIT SAMPLE } & \multicolumn{4}{|c|}{ Cfu $\left(\times 10^{5)}\right.$} \\
\hline & & NAM & MCA & EMB & MSA \\
\hline \multicolumn{6}{|c|}{ LOCAL MARKET } \\
\hline 1 & Ber & 4 & - & 3.4 & - \\
\hline 2 & Grapes & 5.5 & 3.8 & 1.5 & 1.4 \\
\hline 3 & Chickho & 1.9 & 4.0 & 1 & 2 \\
\hline \multicolumn{6}{|c|}{ SUPER MARKET } \\
\hline 1 & Grapes & 2.5 & - & 2.2 & 1.0 \\
\hline \multicolumn{6}{|c|}{ FIELD SAMPLE } \\
\hline 1 & Ber & 8 & - & - & 9 \\
\hline
\end{tabular}

Table.3 Colony morphology of bacterial strains

\begin{tabular}{|l|l|l|l|}
\hline Sr.no & Strain & Colony morphology & Medium \\
\hline 1 & VBL1 & Yellow colour, entire, circular & MS \\
\hline 2 & VCAL2 & Abundant, circular with greenish margin & EMB \\
\hline 3 & VCM3 & Yellow colour, entire, circular & MS \\
\hline 4 & VTL4 & Abundant, circular with greenish margin & EMB \\
\hline 5 & VTL5 & Yellow colour, entire, circular & MS \\
\hline 6 & VCM6 & Yellow colour, entire, circular & MS \\
\hline 7 & VCBL7 & Yellow colour, entire, circular & MS \\
\hline 8 & VTM8 & Yellow colour, entire, circular & MS \\
\hline 9 & VCL9 & Yellow colour, entire, circular & MS \\
\hline 10 & VCAM10 & Yellow colour, entire, circular & MS \\
\hline 11 & VCBM11 & Yellow colour, entire, circular & MS \\
\hline 12 & VCF12 & Yellow colour, entire, circular & MS \\
\hline 13 & VTF13 & Yellow colour, entire, circular & MS \\
\hline 14 & FCHL14 & Yellow colour, entire, circular & MS \\
\hline 15 & FGRL15 & Abundant, circular, with greenish margin & EMB \\
\hline 16 & FCHL16 & Yellow colour, entire, circular & MS \\
\hline 17 & FGRL17 & Pinkish pigment, round entire, & MCA \\
\hline 18 & FBL18 & Pinkish pigment, round entire & MCA \\
\hline 19 & FGRL19 & Yellow colour, entire, circular & MS \\
\hline 20 & FCHL20 & White, oval, moist, round in shape & NA \\
\hline 21 & FBL21 & Abundant, circular, with greenish margin & EMB \\
\hline
\end{tabular}

Table.4 Actual per cent cfu (cell density) decrease

\begin{tabular}{|l|c|}
\hline Compounds (Concentration 3\%) & Range of \% cell density decrease \\
\hline Hydrogen peroxide & 50 \\
\hline Sodium chloride & 48 \\
\hline Calcium chloride & 13 \\
\hline Sodium citrate & 13 \\
\hline Ethanol & 30 \\
\hline
\end{tabular}


Fig.1 Growth of VBL1 on MSA

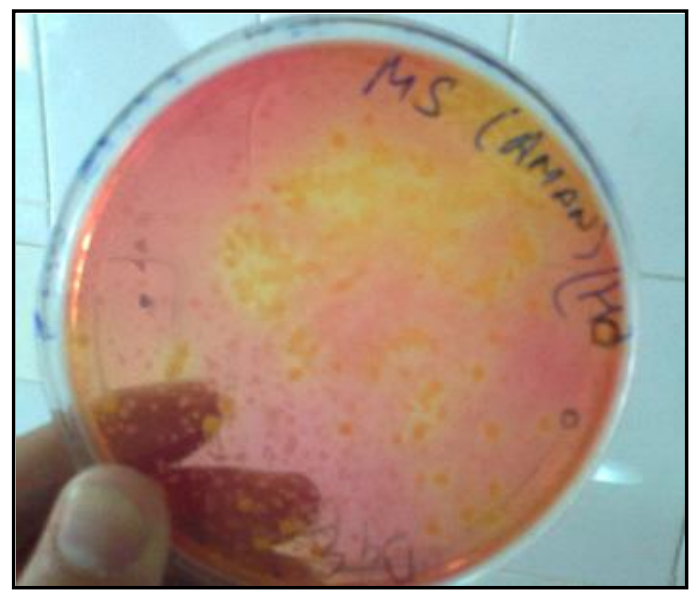

Fig.3 Citrate test

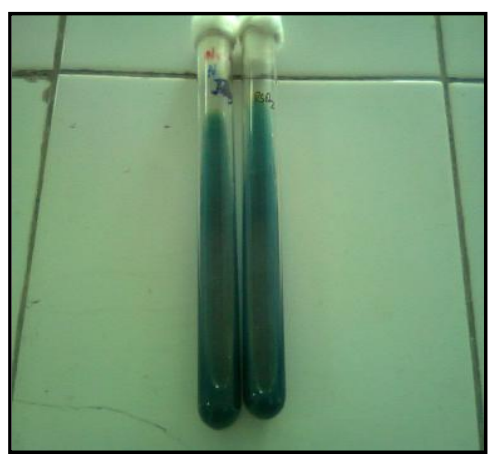

Fig.2 Growth of FGRL15 on EMB

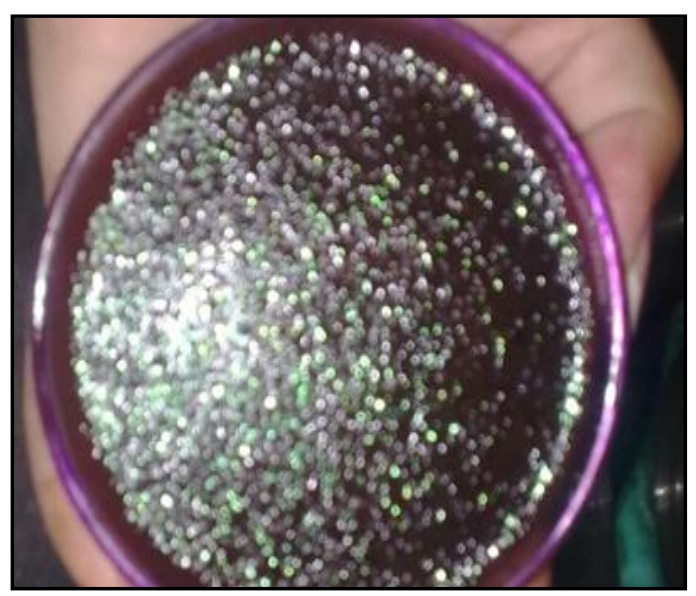

Fig.4 Catalase test

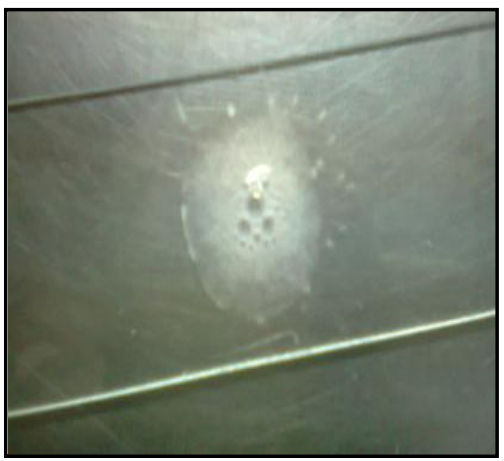

Fig.5 Antibiotic susceptibility patterns of E. coli strains isolated in the present

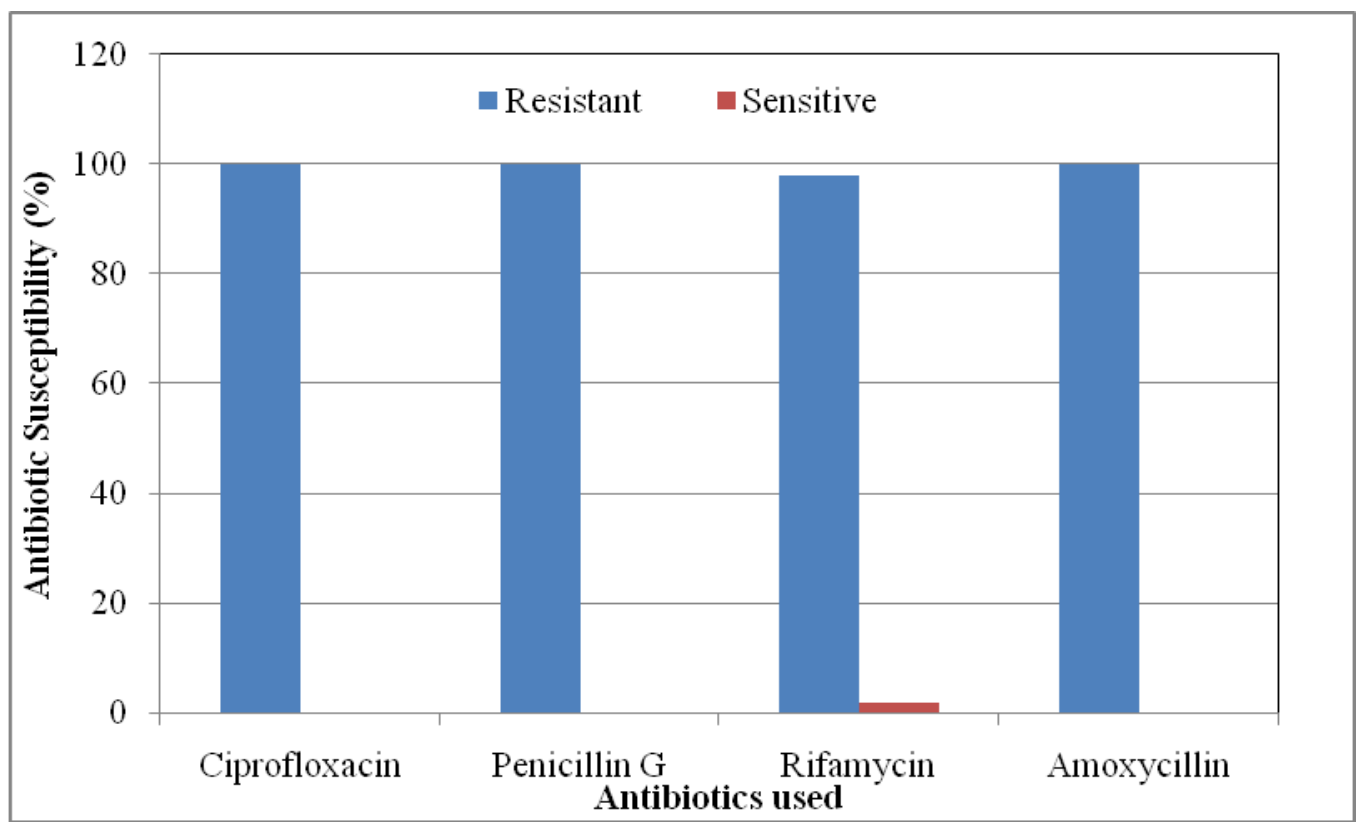


Fig.6 Antibiotic susceptibility patterns among Gram positive strains isolated in the present study

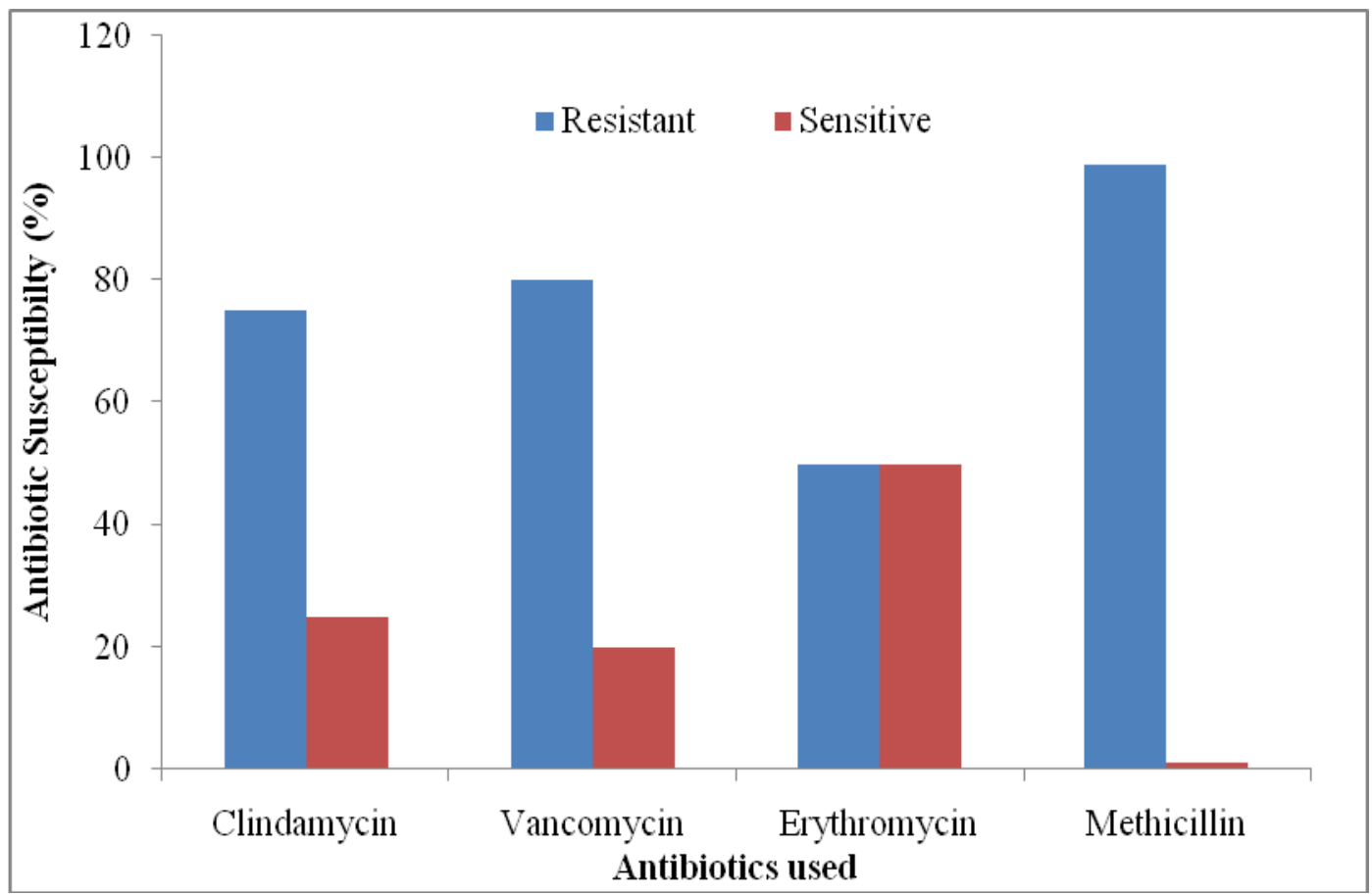

Fig.7 Effect of antimicrobial agents on superficial bacterial population of carrot

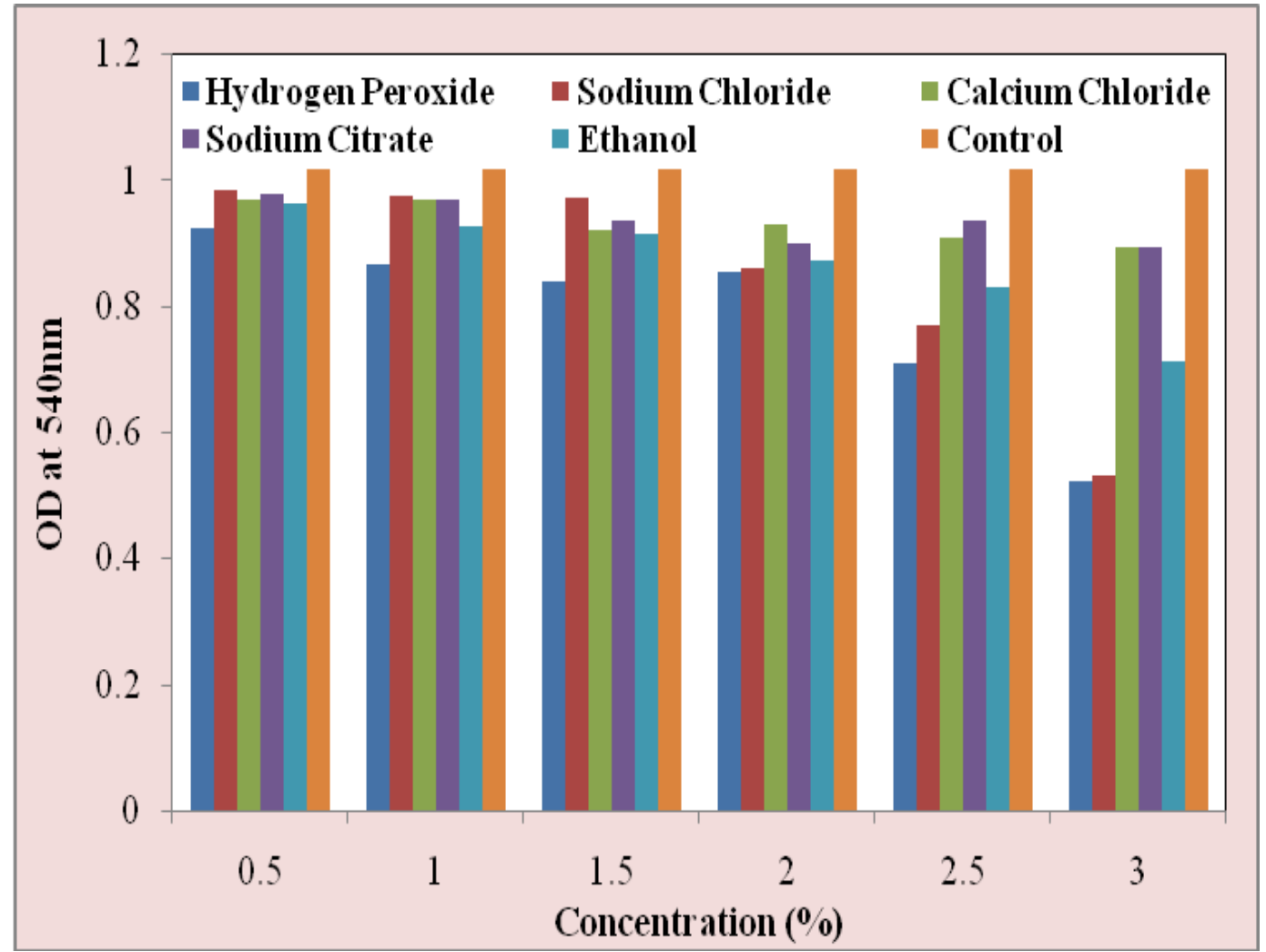


Almost 99 per cent of the E. coli strains were resistant to all the antibiotics tested in the present study (Ciprofloxacin, Penicillin-G, Rifampycin, Amoxicillin) whereas, 75 per cent of the Gram positive strains showed resistance to all the four drugs (Clindamycin, Vancomycin, Erthromycin and Methicillin). Overall, 95\% isolates were resistance to antibiotics that were used in this study (Fig. 5 and 6) Resistance of E. coli for Ciprofloxacin, Penicillin-G, Rifampycin and Amoxicillin has been reported earlier by Akond et al., (2009).

Similar findings on multiple drug resistance of $E$. coli strains has been reported from in several parts of the world by several workers (Khan et al., 2002; Guerra et al., 2003; Zhao et al., 2005; Rahman et al., 2008). High resistance for Amoxycillin among $E$. coli have been also reported by Garba et al., (2009).

Treatment with five antimicrobial agents namely (Hydrogen peroxide, Sodium chloride, Calcium chloride, Sodium citrate and Ethanol) was carried out. Varying concentrations of these agents ranging from $0.5 \%$ to $3.0 \%$ were used and it was observed that all of the agents reduced the cell count to some extent.

$\mathrm{H}_{2} \mathrm{O}_{2}$ was observed to be most effective antimicrobial agent because at its 3\% highest cell reduction was observed $(50 \%)$ Our findings draw support from the work of Patel and Joshi (2008) who reported $\mathrm{H}_{2} \mathrm{O}_{2}$ to be the most effective antimicrobial for the treatment of bacterial load. Saper (1997) has also suggested the efficacy of $\mathrm{H}_{2} \mathrm{O}_{2}$ in improving the microbiological quality and extending the shelf life of fruit and vegetable products. Similarly, Ukuku (2004) reported that treatments of fruits for 5 minutes with Hydrogen peroxide $(2.5 \%$ and $5 \%$ ) caused remarkable reduction in the indigenous surface micro flora of fruits and vegetables.
On the basis of above results it can be concluded that fresh vegetables and fruits mainly from local Market harbour many microbial contaminants and pathogens as compared to samples of super markets, indicating that these are protected from contamination while subsequent handling, packaging, storage and transit. As done by Ibrahim et al., (2009), Patel and Joshi (2008) who observed high contamination and high number of pathogens on the surface of fresh vegetables and fruits in case of local market samples $(\log 9-10 \mathrm{cfu} / \mathrm{ml})$ as compared to super market samples $(\log 5-6 \mathrm{cfu} / \mathrm{ml})$. All the fruits and vegetables assessed bacteriologically had high viable counts even though within the tolerable limit. A good predecontamination of the vegetables as shown by this study could reduce the density of the microbial load by the antibacterial agents used. Similarly Patel and Joshi (2008) who reported $\mathrm{H}_{2} \mathrm{O}_{2}$ to be the most effective antimicrobial for the treatment of bacterial load. A combination of these agents can be used as rinsing agents to reduce the superficial contamination and improve the quality of these fresh fruits and vegetables. Saper (1997) has also suggested the efficacy of $\mathrm{H}_{2} \mathrm{O}_{2}$ in improving the microbiological quality and extending the shelf life of fruit and vegetable products. Similarly, Ukuku (2004) reported that treatments of fruits for 5 minutes with Hydrogen peroxide $(2.5 \%$ and $5 \%$ ) caused remarkable reduction in the indigenous surface micro flora of fruits and vegetables.

\section{References}

Akinyele, B. J. and Akinkunmi, C. O. 2012. Fungi associated with the spoilage of berry and their reaction to magnetic field. Journal of Yeast and Fungal Research 3 (4):49-57.

Asam-Ali, S., Bonkoungou E., Bowe C., deKock C., Godara, A. and Williams 
J.T. (2006). Fruits for the Future 2Revised edition - Ber and other Jujubes (Ziziphus species). Monograph. Pp 289.

Beuchat, L.R. (1996). Pathogenic microorganisms associated with fresh produce. J. Food Prot., 59: 204-206.

Chikwendu, C.I., Nwabueze, R. N. and Anyanwu, B. N. (2008). Antibiotic resistance profile of Escherichia coli from clinically healthy pigs and their commercial farm environments. African Journal of Microbiology Research 2: 012-017.

Cliver, D.O (1997). Food borne viruses. In: Doyle, M.P, Beuchat, L.R. and Montville, T.J (eds.) Food Microbiology: Fundamentals and Frontiers, Washington, DC, American Society for Microbiology, pp 437-446

Einsett, J. and C. Pratt. (1975). Grapes. p. 130-153. Janick J. And Moore, J.N. (Eds.), Advances in fruit breeding. Purdue Univ. Press, West Lafayette, Ind.

FDA, (Food and Drug Administration) (2000). Guide to minimize food safety hazards for fresh fruits and vegetables. Www. Cfsan fda. Gov/ html.

Mansoor-ul-Hassan, F., Mohammed, A., Sagheer, M., Fareed, I., and Muhammad, T. (2005). Residual persistence of chlorpyrifos, imidacloprid and acephate Brinjal fruit. Pak. Entomol. 27: 53.

Mukherjee, A., Speh, D., Jones, A.T.,
Buesing, K.M. and Diez-Gonzalez, F. (2006). Longitudinal microbiological survey of fresh produce grown by farmers in the upper Midwest. Journal of Food Protection 69: 1928-1936.

Patel, S. and Joshi, P. (2008). Microbiological analysis of fresh fruits and vegetables and effect of anti-microbial agents on microbial load. PhD thesis, University of Mumbai.

Silvia, R. Silva, P., Sylvia, E., Frizzo Dariane, C., Pereira, A., Schatkoski, M.B., Gertrudes Corção., R. (2007). Microbiology Quality of Minimally Processed Vegetables Sold In Porto Alegre, Brazil. Brazilian Journal of Microbiology 38: 594-598.

Speer, C.A. (1997). Protozoan parasites acquired from food and water. In: Doyle MP, Beuchat, L.R., Montville TJ (eds.) Food Microbiology: Fundamentals and Frontiers, Washington, DC, American Society for Microbiology. p. 478-493

Wasim A., Paramasivam, M. and Sengupta, D. (2008). Cost reduction in cabbage cultivation by weed control using oryzalin herbicide and hoeing technology. African Journal of Agricultural Research 3: 808-810.

Wells, J.M. and Butterfield, J.E. (1997). Salmonella contamination associated with bacterial soft rot of fresh fruits and vegetables in the marketplace. Plant Dis., 81: 867-872.

\section{How to cite this article:}

Amandeep Kaur, Anchal Sood, Sarbjit Kaur and Priyanka Bhowate. 2017. Bacterial Population Associated with Fruits and Vegetables and its Treatment using Antimicrobial Rinsing. Int.J.Curr.Microbiol.App.Sci. 6(12): 2099-2107. doi: https://doi.org/10.20546/ijcmas.2017.612.240 